\title{
Supported Liquid Membrane Separation of Chromium(VI) from Effluents
}

\author{
Ancy S. Parakudyil ${ }^{1, *}$, K.M. Michael ${ }^{2}$ and Ajai K. Pillai ${ }^{1}$ \\ ${ }^{1}$ Department of Chemistry, Govt. V.Y.T.P.G. Autonomous College, Durg (C.G.), 491001, India \\ ${ }^{2}$ Fuel Reprocessing Division ${ }^{\text {Retd }}$, Bhaba Atomic Research Centre, Bombay 400085, India
}

\begin{abstract}
Supported liquid membrane (SLM) technique was used for the selective separation of Chromium(VI) from iron ore leachates. It was carried out using membrane made of Teflon loaded with Aliquat -336 in n-dodecane. This method is applicable for the removal of chromium(VI) from industrial effluents, and synthetic wastewater. The effect of feed phase, carrier concentration and stripping agent concentrations were studied and optimized. At pH 5.5 SLM transport cell would efficiently separate Chromium(VI) from feed phase to stripping phase.
\end{abstract}

Keywords: Chromium (VI), SLM technique, Teflon loaded with Aliquat -336 in n-dodecane.

\section{INTRODUCTION}

Biological Toxicity of heavy elements are well known. Industries where heavy elements are used often pollute air, water and land by their discharge. One such metal, chromium is widely used in industries in the manufacture of steels, jet engines, tools, paints, photography, electric cells, rubber goods and matches. The salts of chromium are extensively used in metal pickling and plating operations, in the anodizing of aluminum, in leather tanning and in several other industries. Tri-valent chromium salts such as sodium chromate or potassium chromate are generally used in ceramic and glass industries. Since chromium compounds are corrosion inhibitors, they are used to treat cooling tower water. Chromic acid in very dilute quantities is used to protect metals from corrosion [1-4].

Soil and plants contain very little chromium. Sea water contains 1-2.5 ppb of chromium and earth's crust about $200 \mathrm{ppm}$ of chromium. Human body contains about $6 \mathrm{mg}$ of chromium. It accumulates in the lungs as the years go ahead. Chromium bound to Beta globulins is distributed in lungs, heart, brain, liver and spleen [57].

Although both trivalent and hexavalent chromium are reported to be toxic in nature, the latter one is comparatively more hazardous to human being [8,9]. Since most of the industrial effluents have to pass through sewage treatment plants, the bacteria in such plants are destroyed by trace amounts of chromium, thereby rendering the water treatment ineffective. The

*Address correspondence to this author at the S.H. Convent, Balodabazar P.O, Balodabaar (Dt), Chhattisgargh (St), 493332, India; Mob: 919406042332; E-mail: psrancysh@yahoo.com
U.S. Environmental Protection Agency (EPA) regulates the total chromium in drinking water and has set a maximum contamination level (MCL) of $100 \mu \mathrm{g} \mathrm{mL}$. The threshold limit value for Chromium(VI) is $0.5 \mathrm{mg}$ $\mathrm{m}^{-3}$ as proposed by the American Conference of the Governmental Industrial Hygienists [10-11]. Considering its toxic effect and widespread availability it is desirable to determine micro levels of chromium in environmental matrices.

Chromium containing effluents are normally treated to convert Chromium(VI) to Chromium(III) by reduction using $\mathrm{SO}_{2}, \mathrm{NaHSO}_{3}$ or sodium meta bisulphate. $\mathrm{Cr}$ (III) is then precipitated as hydroxide using $\mathrm{NaOH}$. The precipitate is allowed to settle and the clear liquid is disposed off. Recovering chromium from such effluents using cation and anion exchange and reusing the same along with treated water proves a net profit of $\$ 10$ per day for a medium size industry [11].

The tolerance limit of Chromium(VI) is $0.1 \mathrm{ppm}$ in land surface and in potable water is $0.05 \mathrm{ppm}$ (EPA, 1990). Hence, the removal of Chromium(VI) from industrial effluents is important [12]. Diphenylcarbazide is the traditional reagent used for the separation of chromium( $(\mathrm{VI})$ and is determined by spectrophotometric method [13]. But the sensitivity of the method is not high enough ( $\mathrm{mg} / \mathrm{L})$ and the complex formed is also unstable. Azo compounds [14] derivatives of triphenylmethane [15] are the sensitive reagents for the spectrophotometric determination of hexavalent chromium. However, their specificity is not very good and it is necessary to separate the diverse ions before determination

Liquid membranes' application is adopted widely in the field of separation of toxic metals [16]. The membrane acts as a very specific filter for suspended 
solids and other substances. Liquid membranes are used for transporting components at high rates across the membrane through carrier molecule. Carriers alter the guest permeability and facilitate selective diffusion across the membrane. Different types of liquid membranes exist [17-24] i.e., bulk (BLMs), emulsion (ELMs) and supported (SLMs), as well as hollow fibre contained liquid membranes (HFCLMs), SLM contains an organic solution as a carrier, this solution being immobilized in a porous material such as polymers. Cation transport takes place in such a way that it involves the complexation at the feed phase of the membrane and release at the receiving phase. The driving force is a proton concentration difference between the two aqueous phases.

The carrier-rich liquid leaving the extractor is referred to as the raffinate phase and the solvent- rich liquid leaving the extractor is extractant phase. The technology of using immobilized liquid membrane for treating industrial effluents is much more economical and energy efficient [25]. Effluents discharged from industries and leachates from mines can be directly passed through such membranes. Fractional applications of such membrane have been envisaged for the recovery of metals from lean solutions generated in hydrometallurgical operations.

Some membrane separation methods of chromium were ; removal of chromium from aqueous waste solution using liquid emulsion membrane [26], membrane-based hybrid processes for the removal of hexavalent chromium [27], removal of chromium from aqueous solution using cellulose acetate and sulfonated poly (ether ether ketone) blend ultra filtration membranes [28], chromium (VI) from aqueous

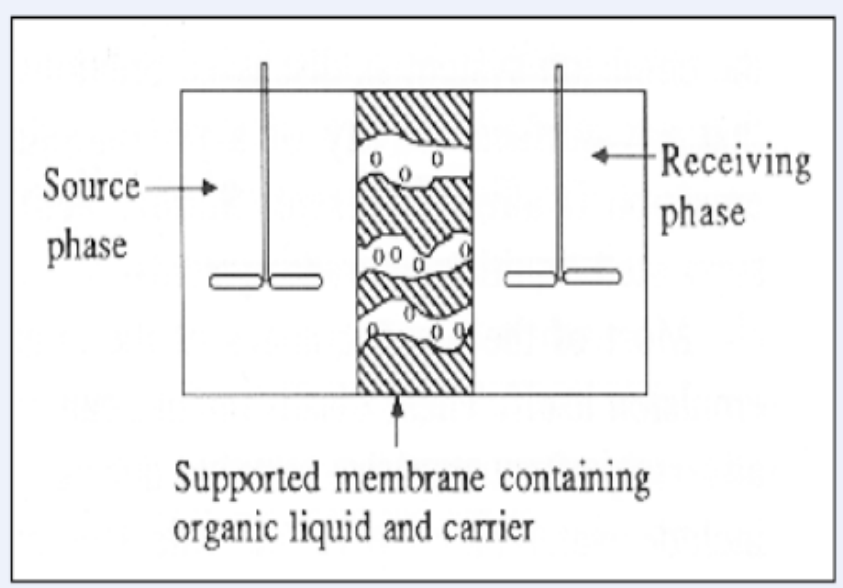

Figure 1: (a) Configuration of SLM. solutions by polymer inclusion membranes [29]. Pilot scale membrane separation of electroplating waste water by reverse osmosis has been reported [30]. Removal of Chromium from Aqueous Solutions by treatment with Carbon Aerogel Electrodes Using Response Surface Methodology [31], removal of trivalent chromium contaminant from aqueous media using FAU-type zeolite membranes are also reported [32].

In the present study, the separation of chromium ions is carried out using a supported liquid membrane (SLM). A liquid membrane is a thin film that selectively permits the passage of a specific constituent from a mixture. Unlike solid membranes, the liquid membranes separate by chemical property rather than size and thus in many ways liquid membrane technology is similar to solvent extraction.

Selective separation and concentration of the solute of interest from dilute solution can be achieved using SLM, where a porous polymeric membrane support impregnated with a solvent, is used as a carrier to separate metal ions. The SLM process is one of the best method of treating waste water containing toxic metals such as Chromium(VI). Aliquat 336 has been shown to be an effective extractant for the separation of Chromium(VI) [33].

Soil samples collected from various mining sites of Chhattisgarh region of India were found to contain chromium (VI) in the range of 75 to $330 \mathrm{ppm}$. This soil when leached with aqua regia almost completely releases chromium (VI). Water leachates around the mines also show Chromium(VI) in the range of 0.04 $0.05 \mu \mathrm{g} / \mathrm{mL}$.

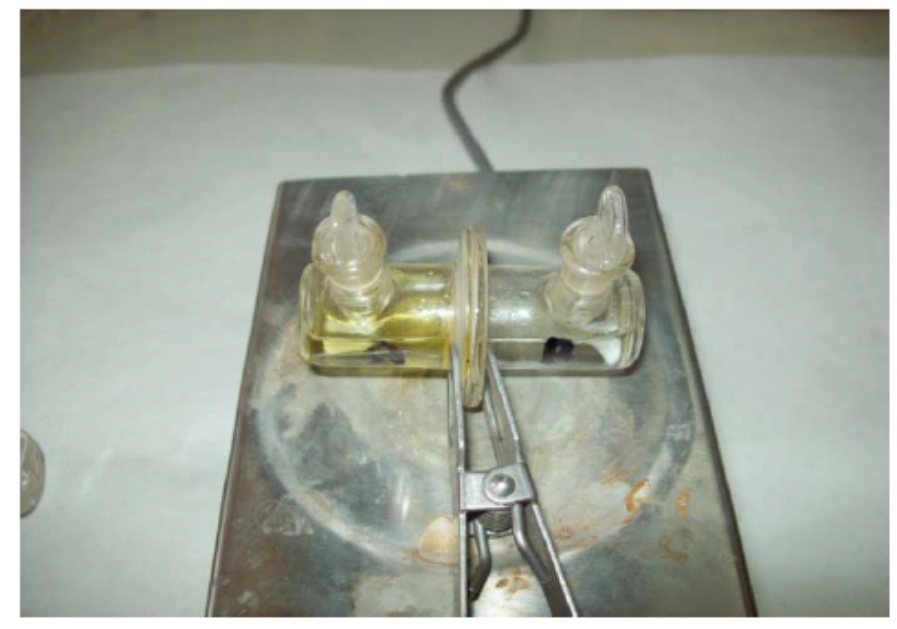

(b) SLM apparatus. 


\section{EXPERIMENTAL}

\subsection{Apparatus}

Absorbance studies were performed in Varian Cary 50 Bio UV-Visible spectrophotometer and Jobin YvonUltrate-238 ICP-AES. pH measurements were made with Systronics $\mathrm{pH}$ meter, model 331. Stirring was done using magnetic stirrer.

\subsubsection{SLM Support Cell}

The membrane is just a porous polymer membrane whose pores are filled with the organic liquid and carrier, set in between the source phase and the receiving phase, which are being gently stirred (Figure 1a and 1b).

\subsection{Reagents}

All the chemicals used were of analytical reagent grade or the highest purity available. Double distilled water was used throughout the experiment for preparation and dilution of reagents as well as samples. Aliquat- 336, n-decanol, Xylene and Kerosene were from Merck, Mumbai, India. Potassium permanganate from Loba chemie Mumbai. Acids: $\mathrm{H}_{2} \mathrm{SO}_{4}, \mathrm{HCl}, \mathrm{HNO}_{3}$ and $\mathrm{NaOH}$ from $\mathrm{Hi}$ Media Laboratories Pvt. Ltd Mumbai.

\section{PROCEDURE}

\subsection{Preparation of Standard Solution of Chromium (VI)}

Stock solution (1000 $\mathrm{mg} \mathrm{mL}^{-1}$ ) was prepared by dissolving $0.2829 \mathrm{~g}$ of $\mathrm{K}_{2} \mathrm{Cr}_{2} \mathrm{O}_{7}$ in double distilled water and volume made up to $100 \mathrm{~mL}$. The working standards were prepared daily by further dilution with double distilled water.

\subsection{Choice of Diluents for Membrane Solvent}

The kerosene and xylene were found to be good diluents for the extractant aliquat 336, but as better result was given by $\mathrm{n}$-dodecane, it was selected for the dilution of the carrier liquid.

\subsection{Preparation of Membrane Support}

Supported liquid membrane is generally prepared by absorbing a solvent on a hydrophobic micro porous polymeric membrane using appropriate diluent. The diluent is generally immiscible with the solutions on the two sides of membrane and should have low dielectric constant. A flat sheet poly tetra fluoro ethylene (PTFE) membrane was used as the polymeric support. The commercial Teflon membrane (PTFE) membrane of 0.45 micrometer diameter, 160 micrometer pore size and $84 \%$ porosity was used. Before impregnation, the membrane support was pre saturated with water for more than two days, dried with bloating paper. Circular pieces of this PTFE membrane were soaked in the carrier solution, aliquat 336 (in nitrate medium) of different concentrations for $12 \mathrm{Hrs}$ before use to have uniform adsorption of carrier solution. The membrane was then removed from the organic solution, rinsed with water, wiped with filter paper to ensure the removal of excess carrier.

\subsection{Supported Liquid Membrane Transport Mechanism}

The membrane was fitted in the middle of a glass apparatus which makes the apparatus into two compartments. The feed solutions used were of various concentrations of $\mathrm{K}_{2} \mathrm{Cr}_{2} \mathrm{O}_{7}$ and the strip solution was $\mathrm{NaOH}$ of different concentrations. These feeds and strips were separated by the membrane. Constant stirring of both the compartments were done with magnetic stirrers. Samples were taken at periodic intervals. The volume of the sample removed is always accounted for.

Schematic diagram of the SLM cell is shown in Figure 2. The hydrophobic SLM whose pores are filled with the organic phase fitted between feed phase and stripping phase. The extraction of Chromium(VI) as the chromate ion from the aqueous feed with aliquat 336 (a long chain quaternary amine) is described by the chemical equation.

$2 \mathrm{R}_{3} \mathrm{NCH}_{3} \mathrm{NO}_{3}+\mathrm{CrO}_{4}{ }^{2-} \rightarrow\left(\mathrm{R}_{3} \mathrm{CH}_{3} \mathrm{~N}\right)_{2} \mathrm{CrO}_{4}+2 \mathrm{NO}_{3}{ }^{-}$

\subsection{Procedure of Supported Liquid Membrane (SLM) Experiment}

About $30 \mathrm{~mL} 2.5 \times 10^{-3} \mathrm{molL}^{-1}$ of Chromium(VI) in nitric acid was taken in the feed compartment. The impregnated SLM - PTFE was kept at the middle of the port and in the receiving compartment $1 \mathrm{M} \mathrm{NaOH}$ solution was taken. Both feed solution and strippant solutions were stirred with a magnetic stirrer at room temperature continuously. The initial $\mathrm{pH}$ of the solution was maintained at 5.5. The colour reduction in the feed solution and increase in colour intensity of the strippant was visually noticeable. Samples were drawn at intervals of one hr from both compartments. The concentration of chromium (VI) was ascertained using 
Coupled transport interfacial Ion - Exchange Reaction
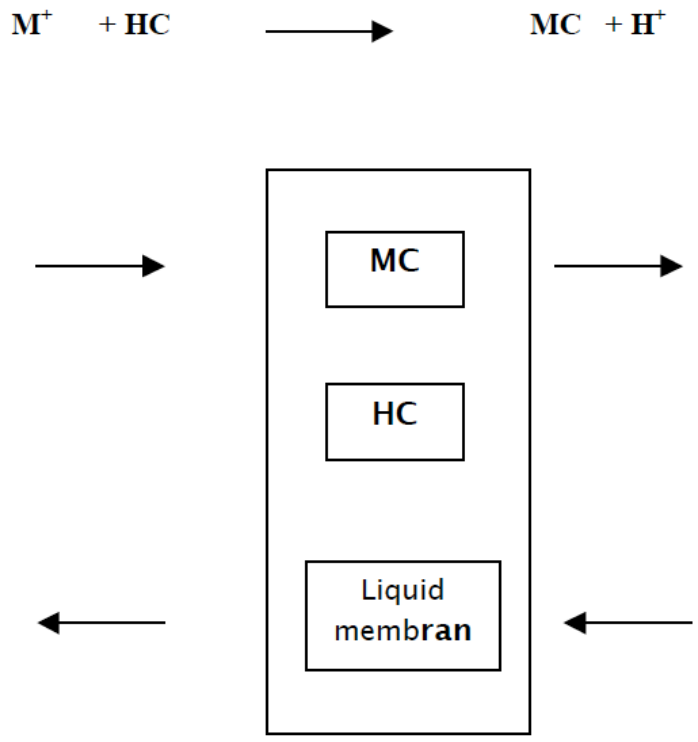

Source phase

Receiving phase

Figure 2: Schematic diagram of the coupled transport mechanism for metal ion transport through a liquid membrane $\left(\mathrm{M}_{+}\right.$is the metal ion $\mathrm{HC}$ is the ion exchange reagent and $\mathrm{H}+$ is the hydrogen ion.

ICP-AES. The absorption intensity of yellow color was measured at $445 \mathrm{~nm}$.

\subsection{Enrichment Factor}

Enrichment factor is one of the most common criteria used to evaluate a particular SLM system. The application of SLM is often aimed at the enrichment of a solute as opposed to selective separation. In the liquid membrane system the feed phase is usually composed of a more concentrated solution than the stripping phase. The enrichment factor $(E)$, which is defined as the ratio of the concentration of the species in the stripping solution $S_{s}$ to the initial concentration in the feed solution $\left(\mathrm{S}_{\mathrm{f}}\right)$ [34].

\section{$E=\left(S_{s}\right) /\left(S_{f}\right)$}

In supported-liquid membrane extractions, high enrichment factors are a result of high solubility of the analytes into the membrane and trapping metals in the acceptor phase. In this, the trapping in the acceptor phase allows additional enrichment. As described by a simple theory, infinitely large enrichment factors can be obtained with SLM extraction as the concentration of uncharged analyte in the acceptor is kept at zero. In reality, the high enrichment factors are limited by the processing time and the available sample volume. Sometimes, the $p K a$ of the compound may also limit the enrichment factors if it does not allow complete trapping in the acceptor phase.

\section{RESULTS AND DISCUSSION}

\subsection{Effect of pH}

$\mathrm{pH}$ of the system, is an important factor in the selective separation and distribution of metal ion species in aqueous phase and it acts as the main variable in the extraction of Chromium(VI). The effect of feed phase on the transport of Chromium(VI) was examined from $\mathrm{pH} 2$ to 8 , maintaining the feed phase $\mathrm{Cr}(\mathrm{VI})$ at fixed concentration $\left(2.5 \times 10^{-3} \mathrm{~mol} \mathrm{~L}^{-1}\right)$. It is found that there was no transport of Chromium(VI) below $\mathrm{pH}$ 4.5. Since the carrier aliquat 336 forms complex with Chromium(VI) only at $\mathrm{pH}>4.5$, chromium could not be extracted at lower $\mathrm{pH}$ due to lack of complex formation. From Figure $\mathbf{3}$ it is clear that optimum condition for the separation of $\mathrm{Cr}(\mathrm{VI})$ is at $\mathrm{pH}$ 5.5 beyond which a dip in extraction is noticeable which may be due to the formation of neutral complexes.

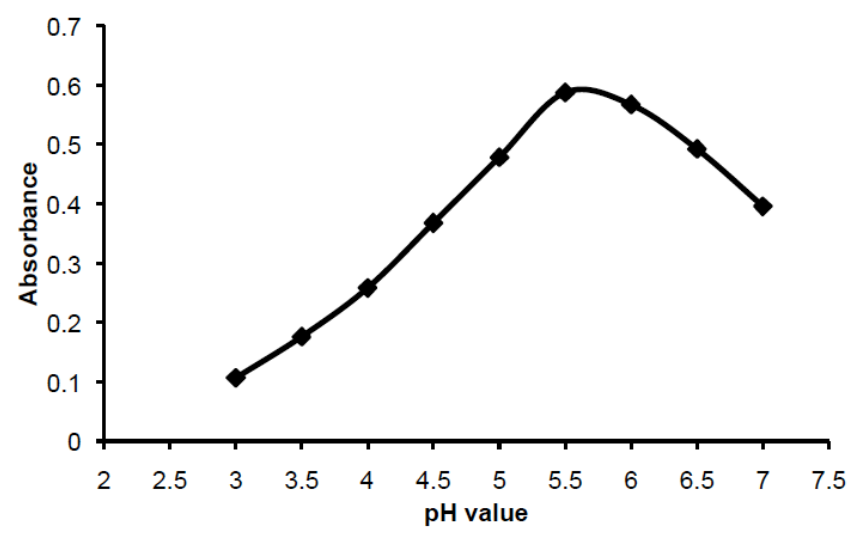

Figure 3: Effect of $\mathrm{pH}$ in separation technique.

\subsection{Optimization of the SLM Enrichment Procedure}

The carrier concentration in the SLM system is one of the important factor for selective transport of metal ions. In the case of chromium separation aliquat 336 was found to be a suitable carrier due to higher ionization nature of aliquat 336 at $5.5 \mathrm{pH}$.

Hexavalent chromium, \&(VI), may exist in the aqueous phase in different forms; the total amount of chromium and the $\mathrm{pH}$ are the main variables of the chromium species in an aqueous phase. If there is no other chemical species in the aqueous solution, the $\mathrm{Cr}(\mathrm{V} 1)$ equilibrium reactions are:

$\mathrm{H}_{2} \mathrm{CrO}_{4} \rightarrow \mathrm{H}++\mathrm{HCrO}_{4}^{-} \quad(\log \mathrm{K}=-0.8)$ 
Table 1: Transport of Chromium(VI) lons Across the Liquid Membrane Chromium(VI) Concentration $=2.5 \times 10^{-3} \mathrm{~mol} \mathrm{~L}^{-1}$, Aliquat 336 Conc.\% 1-30\%, NaOH Concentration 0.01- 4 m/L

\begin{tabular}{|c|c|c|c|}
\hline $\begin{array}{c}\text { NaOH } \\
\text { Concentration mol/L }\end{array}$ & $\begin{array}{c}\text { Max. Absorbance } \\
\text { value }\end{array}$ & $\begin{array}{c}\text { Aliquat 336 } \\
\text { Conc.\% }\end{array}$ & $\begin{array}{c}\text { Max. } \\
\text { Absorbance }\end{array}$ \\
\hline \hline 0.01 & 0.018 & $1 \%$ & 0.101 \\
\hline 0.05 & 0.063 & $3 \%$ & 0.297 \\
\hline 0.1 & 0.078 & $5 \%$ & 0.359 \\
\hline 0.5 & 0.122 & $10 \%$ & 0.361 \\
\hline 1 & 0.439 & $15 \%$ & 0.362 \\
\hline 2 & 0.445 & $20 \%$ & 0.367 \\
\hline 3 & 0.502 & $30 \%$ & 0.368 \\
\hline
\end{tabular}

$\mathrm{H}_{2} \mathrm{CrO}_{4} \rightarrow \mathrm{H}++\mathrm{CrO}_{4}^{2-}(\log \mathrm{K}=-6.5)$

$2 \mathrm{H}_{2} \mathrm{CrO}_{4} \rightarrow \mathrm{Cr}_{2} \mathrm{O}_{7}^{2-}+\mathrm{H}_{2} \mathrm{O}(\log \mathrm{K}=1.52)$

$\mathrm{HCr}_{2} \mathrm{O}_{7} \rightarrow \mathrm{H}++\mathrm{Cr}_{2} \mathrm{O}_{7}^{2-}(\log \mathrm{K}=0.07)$

Under the present experimental conditions, hydrogen ion present in the carrier was exchanged for metal ion complexation. Transport of Chromium(VI) from the mixture of metal ions for varying concentrations of carrier ( aliquat- 336) was studied. It can be seen that the absorbance increases with increase in concentration of $\mathrm{NaOH}$, Chromium( $\mathrm{VI})$ and aliquat -336 (Table 1). However high concentration of aliquat -336 is not required for the impregnation of the membrane hence for further experiments only $10 \%$ was utilized. The strippant $\mathrm{NaOH}$ was also not required in high concentration. There is always a possibility of osmotic transfer in both compartments. Dilute solutions are better for experiments. Hence $1 \mathrm{M} \mathrm{NaOH}$ was used as strippant.

\subsection{Effect of Concentration of Strippant Solution on the Transport of Chromium(VI)}

Since the SLM technique involves simultaneous extraction and stripping process for the continuous transport of metal ions, it is necessary to find the effect of stripping agent in the receiving phase. The effect of stripping agent concentration on the Chromium(VI) transport was investigated using various concentration of $\mathrm{NaOH}$ solution. The concentration of alkali varied from $1 \mathrm{M}$ to $4 \mathrm{M}$ and the result obtained are shown in Table 2. The stripping efficiency is maximum at $3.35 \mathrm{M}$. However at higher concentration the excess ions tends to form an ionic atmosphere thereby causing reduction in stripping efficiency Figure 4.

\subsection{Optimization of the SLM Enrichment Procedure}

It can be seen from Table 3 that though 50\% transport is possible within $3 \mathrm{hrs}$, reversal takes place afterwards. It may be due to the concentration barriers and osmotic pressures. As $1 \mathrm{M} \mathrm{NaOH}$ also does equally good in stripping chromium, it is preferable to use $1 \mathrm{M}$ $\mathrm{NaOH}$. In order to overcome the reverse transport, the Chromium(VI) concentration in the feed compartment was reduced to $2.5 \times 10^{-4} \mathrm{~mol} \mathrm{~L}^{-1}$ and $1 \mathrm{M} \mathrm{NaOH}$ was used as strippent Figure 4.

\subsection{Separation of Chromium(VI) from Effluent Water}

The details of application of SLM in separating $\mathrm{Cr}$ (VI) from effluent samples collected from separating

Table 2: Chromium(VI) Concentration $-2.5 \times 10^{-3} \mathrm{~mol} \mathrm{~L}^{-1}$ at pH 5.42 (Reagent) NaOH Concentration- 1 mol L ${ }^{-1}$ (strippent), Volume of Each Compartment - 3.5ml Chromium Taken in Reagent Compartment - 449.537 $\mathrm{ggm} \mathrm{L}^{-1}$, Acid Medium Used $-\mathrm{HNO}_{3}$

\begin{tabular}{|c|c|c|c|}
\hline $\begin{array}{c}\text { Time } \\
\text { Hrs }\end{array}$ & $\begin{array}{c}\text { Vol. after } \\
\text { Sampling (ml) }\end{array}$ & $\begin{array}{c}\text { Chromium in strip } \\
\text { Mgm }\end{array}$ & $\begin{array}{c}\text { \% of Cr } \\
\text { transport }\end{array}$ \\
\hline \hline 0 & 3.5 & Nil & Nil \\
\hline 1 & 3.5 & 199.794 & 44.44 \\
\hline 2 & 3.45 & 216.356 & 48.83 \\
\hline 3 & 3.4 & 164.70 & 37.72 \\
\hline 4 & 3.35 & 189.21 & 43.97 \\
\hline 5 & 3.3 & 174.45 & 41.15 \\
\hline
\end{tabular}


Table 3a: Determination of Chromium in Leachates from Open Cast Iron Ore Mines. Volume of Leachate Sample Used $(4 \mathrm{ml})$

\begin{tabular}{|c|c|c|}
\hline Sample No & Present method $(\boldsymbol{\mu g})$ & Reported method $(\boldsymbol{\mu g})$ \\
\hline \hline 1 & 0.401 & 0.360 \\
\hline 2 & 0.160 & 0.120 \\
\hline 3 & 0.472 & 0.456 \\
\hline
\end{tabular}

Table 3b: Determination of Chromium in Steel Sample No. BS- 94614

\begin{tabular}{|c|c|c|c|}
\hline \multirow{2}{*}{$\begin{array}{c}\text { Steel } \\
\text { sample }\end{array}$} & \multirow[t]{2}{*}{ Certified value } & \multicolumn{2}{|c|}{ Chromium found in } \\
\hline & & Present method & Reported method \\
\hline sample & $0.06 \%$ & $0.059 \%$ & $0.056 \%$ \\
\hline No.BS 94614 & $0.06 \%$ & $0.057 \%$ & $0.056 \%$ \\
\hline $0.1 \mathrm{~g}$ & $0.06 \%$ & $0.058 \%$ & $0.058 \%$ \\
\hline
\end{tabular}

mixture is given in Table $\mathbf{3 a}$ and $\mathbf{3} \mathbf{b}$. It was seen that quatitative separation of $\mathrm{Cr}(\mathrm{VI})$ is possible with the current SLM technique.

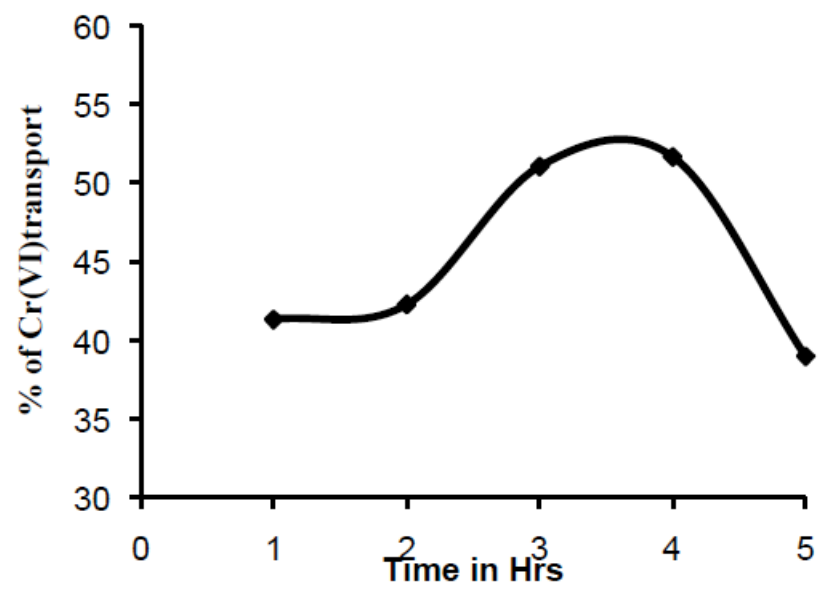

Figure 4: Effect of concentration of strippant solution on the transport of Chromium(VI).

\section{CONCLUSION}

SLM technique is sensitive and easy procedure for the selective separation of metal ions from aqueous solution. It's cell design is very simple. It requires the use of very little solvent. Thus it makes economical to use even costly solvents. The chromium (VI) content of the leachates of mine and industrial effluents can be easily separated using SLM made up of aliquat-336. It is quaternary amine and is biodegradable. Hence it posses no environmental problems. Hollow fiber method can be used for large scale separation of metal ions in the place of SLM.

\section{ACKNOWLEDGEMENT}

The author is grateful to D S T- F I S T for providing instrumentation facilities and Chemistry Department, Govt. V.Y.T. P G Autonomous College Durg for providing lab facilities.

\section{REFERENCES}

[1] Ray PC. J Ind Chem Soc 1924; 1: 207.

[2] Singanan M, Vinodhini S, Alemayehu A. J Environ Prot 2006; 26(5): 385-91.

[3] Singanan M, Singanan V, Abebaw A. Ind J Environ Res 2008; 2: 177-82.

[4] Donald M, Bajwa CW. Sep Sci 1977; 12: 435-5. http://dx.doi.org/10.1080/00372367708058088

[5] Cherian T, Narayana B. Ind J Chem Technol 2005; 12 : 596.

[6] Eckert JM, Judd RJ, Lay PA, Symons AD. Anal Chim Acta 1991; 255: 31. http://dx.doi.org/10.1016/0003-2670(91)85083-5

[7] Hafiane A, Lemordant D, Dhahbi M. J Desalination 2000; 130: 305-12.

[8] Narayana B, Cherian T. J Braz Chem Soc 2005; 16: 197.

[9] Cameron RE. Guide to Site and Soil Description for Hazardous Waste Site Characterisation 1992; 1.

[10] Standard Methods for the Examination of Water and Wastewater American Public Health Association, 19th ed, Washington 1995; p. 3.

[11] Soko L, Chimuka L, Cukrowska E, Pole S. Anal Chim Acta 2003; 485: 25. http://dx.doi.org/10.1016/S0003-2670(03)00396-9

[12] Reports of Committee on Water Quality Criteria, FWPCA U.S. Dept. of Interior 1968.

[13] Box M. Anal Chem Acta 1954; 10: 209-21.

[14] Li HZ, Zhan J, Yang CX. Chinese J Env Scn 1995; 16: 64-6.

[15] Scott K, Ibhadon A. J Chem Eng 1994; 2: 195-201. 
[16] Marchese J, Valenzuela F, Basualto C, Acosta A, Marchese J. Hydrometallurgy 2004; 72: 309-17. http://dx.doi.org/10.1016/j.hydromet.2003.07.003

[17] Mulder M. Basic Principles of Membrane Technology, Kluwer Academic, Dordrecht 1996. http://dx.doi.org/10.1007/978-94-009-1766-8

[18] Chimuka L, Mathiasson L, Jönsson JÅ. Anal Chim Acta 2000; $416: 77$. http://dx.doi.org/10.1016/S0003-2670(00)00853-9

[19] Tavlarides LL, Bae JH, Lee CK. Solvent Extraction, Membranes and Ion Exchange in Hydrometallurgical Dilute Metals Separation. Sep Sci Technol 1987; 2: 581-7. http://dx.doi.org/10.1080/01496398708068970

[20] Santoyo AB, Carrasco JLG, Gomez EG, Martin MFM, Montesinos AMH. Desalination 2004; 160: 151-8. http://dx.doi.org/10.1016/S0011-9164(04)90005-7

[21] Neplenbroek AM, Bargeman D, Smolders CA. J Membr Sci 1992; 67: 149.

http://dx.doi.org/10.1016/0376-7388(92)80022-C

[22] Jönsson JÅ, Mathiasson L. J Sep Sci 2001; 24: 495. http://dx.doi.org/10.1002/16159314(20010801)24:7<495::AID-JSSC495>3.0.CO;2-B

[23] Djane N, Ndung'u K, Johnsson C, Sartz H, Törnström T, Mathiasson L. Talanta 1999; 48: 1121. http://dx.doi.org/10.1016/S0039-9140(98)00334-8

[24] Neplenbroek AM, Bargeman D, Smolders CA. J Membr Sci 1992; 67: 133. http://dx.doi.org/10.1016/0376-7388(92)80021-B

[25] Papantoni M, Djane NK, Ndungu K, Jönsson JA, Mathiasson L. Analyst 1995; 120: 1471. http://dx.doi.org/10.1039/an9952001471
[26] Bartsch RA, Way J, Chemical Separations with Liquid Membranes. Am Chem Soc, Washington, DC, 1996; ACS Symp. Ser. 642.

[27] Hasana MA, Selima YT, Mohamed KM. Removal of chromium from aqueous waste solution using liquid emulsion membrane. J Hazardous Mater 2009. http://dx.doi.org/10.1016/j.jhazmat.2009.03.030

[28] Kulkarni PS, Kalyani V, Mahajani VV. Removal of Hexavalent Chromium by Membrane-Based Hybrid Processes. Indust Eng Chem Res 2007; 46(24): 8176-82.

[29] Arthanareeswaran G, Thanikaivelan P, Jaya N, Mohana D, Raajenthiren M. J Hazardous Materials B 2007; 139: 44-49. http://dx.doi.org/10.1016/i.jhazmat.2006.06.006

[30] Kozlowski C, Walkowiak W. Removal of chromium(VI) from aqueous solutions by polymer inclusion membranes. Water Res 2002; 36: 4870-76. http://dx.doi.org/10.1016/S0043-1354(02)00216-6

[31] Chai X, Chen G, Yue P, Mi Y. Pilot scale membrane separation of electroplating waste water by reverse osmosis. J Membr Sci 1996; 123: 235-42.

http://dx.doi.org/10.1016/S0376-7388(96)00217-7

[32] Covarrubiasa C, Garcia R, Arriagada R, Anez JY, Ramananb H, Lai BZ, Tsapatsis M. J Membr Sci 2005; 312: 163-73.

[33] Kabay N, Arda M, Saha B, Streat M. Reactive Functional Polymers 2003; 54: 103-15. http://dx.doi.org/10.1016/S1381-5148(02)00186-4

[34] Wen-Jun LA. Chao TA, Xue-Xun GA. Inrern J Environ Anal Chem 2003; 81: 127-35. 